\title{
In Vitro Antioxidant Activity of Zingiber officinale, Piper retrofractum, and Their Combinations
}

\author{
Hendri Wasito*, Heny Ekowati, Fitri Fauziah Hayati \\ Department of Pharmacy, Medicine and Health Sciences Faculty, \\ Jenderal Soedirman University \\ Jln. Dr. Soeparno, Karangwangkal, Purwokerto
}

\begin{abstract}
Many plants are used empirically as antioxidant. Plants that are frequently used in Indonesian communities are Zingiber officinale and Piper retrofractum. The aim of this research was to investigate the in vitro antioxidant activity of single ethanolic extract and the combinations of Z. officinale and $P$. retrofratum using free radical scavenging DPPH (I,I-diphenyl2-picrylhydrazyl) method. $Z$. officinale and $P$. retrofratum were extracted by maceration using $95 \%$ ethanol for $3 \times 24$ hours. Antioxidant activity was evaluated using I,I-diphenyl-2picrylhydrazyl (DPPH) method. The concentration of the extract $(\mu \mathrm{g} / \mathrm{mL})$ that was required to scavenge $50 \%$ of free radicals $\left(\mathrm{IC}_{50}\right)$ was calculatedusing the percent scavenging activities of six different extract concentrations. The results showed that the single ethanolic extract of $Z$. Officinalle produced the highest antioxidant activity with $\mathrm{IC}_{500} 56 \mu \mathrm{g} / \mathrm{mL}$, while the antioxidant activity of the single ethanolic extract of $P$. retrofractum produced an $I_{50}$ of $3.445 \mu \mathrm{g} / \mathrm{mL}$. The $I C_{50}$ of combination of $Z$. officinale and $P$. retrofratum ethanolic extracts at concentration ratios of I: $2, \mathrm{I}: \mathrm{I}$, and 2 : I were I $48 \mu \mathrm{g} / \mathrm{mL}, 85 \mu \mathrm{g} / \mathrm{mL}$, and $73 \mu \mathrm{g} / \mathrm{mL}$.
\end{abstract}

Keywords: Zingiber officinale, Piper retrfratum, Antioxidant, DPPH

\section{INTRODUCTION}

Oxidative stress induced by Reactive Oxygen Species (ROS) is implicated in the pathogenesis of a variety of vascular and neurological diseases, including cancer, atherosclerosis, hypertension, coronary artery diseases, and other diseases. Damage due to freeradicals caused by ROS leads toseveral downstream effects as they can attack lipids, protein or enzymes, carbohydrates, and DNAin cells and tissues. Theyinduce undesirable oxidation, causing membranedamage, protein modification, DNA damage, and cell death induced by DNA fragmentation and lipidperoxidation (Singh et al., 2004). Antioxidants can terminate or retard the oxidation process by scavenging free radicals, chelating free catalytic metals andalso by acting as electron donors (Senevirathne et. al., 2006).

Plants thatcan be a potential source of natural antioxidants as Zingiber officinale and Piper retrofractum (Jagdale et. al., (2009); Shirin and Parakash, (2010)). Z. Officinale contains gingerol compounds and derivatives such as polyphenols that have antioxidant effects (Ghosh, 2011). P. retrofractum contains essential oils such as terpenoids that have been reported as antioxidants (Grassman, 2005). According to Nakatani, et. al., (1986) and Kametani, et. al., (2005) compoundsthat act as antioxidants in $P$. Retrofractum is feruperine. According Dyatmiko (2000) piperine and amide phenol compounds in the P.retrofractum has antioxidant activity.

The development of traditional or natural medicine at this time leads to the use of a combination of crops (Beinfield and Korenglod, 2005). The combination of several types of antioxidants provide better protection against oxidation compared with only one type of antioxidant (Simanjuntak et.al., 2008). The present study aimed to evaluate the antioxidant activity of $Z$. officinale, $P$. retrofractum and their combinations use of the stable free radical 1,1diphenyl-2-picrylhydrazyl (DPPH) for estimating antioxidant activity.

\section{MATERIALS AND METHODS}

\section{Material}

Z. officinale, $P$. retrofractum, ethanol, aquades, 1,1-diphenyl-2-picrylhydrazyl (DPPH) (ABCR GmbH, Germany). All chemicals and reagents used were analytical grade.

\footnotetext{
*Corresponding author e-mail : hendri.apt@gmail.com
} 


\section{Preparation of extracts}

$Z$. officinale and $P$. retrofractum extracted by maceration using $96 \%$ ethanol for $3 \times 24$ hours. The filtered extract was concentrated underreduced pressure to remove the solvent.

\section{Antioxidant assay (DPPH free radical scavenging activity)}

The free radical scavenging activity of different concentration of single ethanolic extract and their combinations (1:2), (1:1), and (2:1) from $Z$. officinale and $P$. retrofratum were measured using DPPH. The method modified by BrandWilliams (1995) and James, et al. (2009). Two milliliters of each dilution of single ethanolic extract and their combinations were added to two $\mathrm{ml}$ of $100 \mu \mathrm{M}$ solution of DPPH in ethanol. After 30 minutes absorbance was measured at $\lambda 517 \mathrm{~nm}$ using a spectrophotometer. A $100 \mu \mathrm{M}$ solution of DPPH in ethanol was used as DPPH control. All tests were performed in triplicate. Percent inhibition was calculated using the following equation, where Abs (sample absorbance), and Abk (DPPH control absorbance). The mean of three $\mathrm{IC}_{50}$ (concentration causing $50 \%$ inhibition) value of each sample extract was determined graphically.

$$
\% \text { inhibition }=[(\mathrm{Abk}-\mathrm{Abs}) / \mathrm{Abk}] \times 100
$$

\section{RESULTS AND DISCUSSION}

The concentration of the extract $(\mu \mathrm{g} / \mathrm{mL})$ that was required to scavenge $50 \%$ of radicals
$\left(\mathrm{IC}_{50}\right)$ was calculated by using the percent scavenging activities of six different extract concentrations. The $\mathrm{IC}_{50}$ was calculated graphically using a calibration curve in the linear range by plotting the extract concentration $v s$. the corresponding scavenging effect.The smaller the $\mathrm{IC}_{50}$ of a compound, the higher activity compound as antioxidant.

Table I showed the free radical scavenging activity $\left(\mathrm{IC}_{50}\right)$ of different concentration of single ethanolic extract and their combinations (1:2), (1:1), and (2:1) from $Z$. officinale and $P$. Retrofratum. The results showed that the single ethanolic extract of $Z$. Officinalle showed the biggest antioxidant activity $\left(\mathrm{IC}_{50} 56 \mu \mathrm{g} / \mathrm{mL}\right)$, while the antioxidant activity $\left(\mathrm{IC}_{50}\right)$ of the single ethanolic extract of $P$. retrofractum was 3.445 $\mu \mathrm{g} / \mathrm{mL}$. Antioxdant activity $\left(\mathrm{IC}_{50}\right)$ combination of $Z$. officinale and $P$. retrofratum ethanolic extrac (1: 2),(1:1), and (2:1) were $148 \mu \mathrm{g} / \mathrm{mL}, 85 \mu \mathrm{g} / \mathrm{mL}$, and $73 \mu \mathrm{g} / \mathrm{mL}$. The combination of higer types of antioxidants (Z. officinale $\left(\mathrm{IC}_{50} 56 \mu \mathrm{g} / \mathrm{mL}\right.$ ) with lower types ( $P$. Retrofractum $\mathrm{IC}_{50} 3445 \mu \mathrm{g} / \mathrm{mL}$ ) provide better protectionas antioxidant compared with only one type of lower antioxidant. The observed differential scavenging activities of the extracts against the DPPH system could be due to the presence of different compounds in the extract. According to Djeridane, et al., (2006), the antioxidants in the combination extract makes the antioxidant activity not only dependant onthe concentration, but also on the structure and the interaction between the antioxidants.

Table I. In vitro antioxidant activity of various extract sample

\begin{tabular}{|c|c|c|}
\hline Extract Sample & $\begin{array}{c}\mathrm{I} \mathrm{C}_{50} \\
(\mu \mathrm{g} / \mathrm{mL})\end{array}$ & $\begin{array}{c}\text { Mean IC } 50 \\
(\mu g / m L)\end{array}$ \\
\hline \multirow{3}{*}{$\begin{array}{l}\text { Z. officinale } \\
\text { (single extract) }\end{array}$} & 58 & \multirow{3}{*}{56} \\
\hline & 55 & \\
\hline & 56 & \\
\hline \multirow{3}{*}{$\begin{array}{l}\text { P. retrofractum } \\
\text { (single ekstract) }\end{array}$} & 3517 & \multirow{3}{*}{3445} \\
\hline & 3570 & \\
\hline & 3246 & \\
\hline \multirow{3}{*}{$\begin{array}{l}\text { Z. officinale and P. Retrofratum } \\
\text { ( Combination } 1: 2 \text { ) }\end{array}$} & 144 & \multirow{3}{*}{147} \\
\hline & 156 & \\
\hline & 144 & \\
\hline \multirow{3}{*}{$\begin{array}{l}\text { Z. officinale and } P \text {. Retrofratum } \\
\text { (Combination } I: I)\end{array}$} & 79 & \multirow{3}{*}{85} \\
\hline & 81 & \\
\hline & 96 & \\
\hline \multirow{3}{*}{$\begin{array}{l}\text { Z. officinale and P. Retrofratum } \\
\text { ( Combination 2:I) }\end{array}$} & 73 & \multirow{3}{*}{73} \\
\hline & 74 & \\
\hline & 70 & \\
\hline
\end{tabular}


The free radical scavenging activity was investigated in DPPH assay.Scavenging of DPPH free radical is the basis of a common antioxidant assay (Sharma and Bhat, 2009).The molecule of 1,1-diphenyl-2-picrylhydrazyl (DPPH) is a stable free radical because of the delocalisation of the spare electron over the molecule as a whole, so that the molecules do not dimerise, as would be the case with most other free radicals. The delocalisation also gives rise to the deep violet colourin ethanol solution (Molyneoux, 2004).

When a solution of DPPH is mixed with that of a substance that can donate a hydrogen atom, then this gives rise to the reduced form with the loss of this violet colour, although there would be expected to be a residual pale yellow colour from the picryl group still present (Molyneoux, 2004), thus we have estimated theantioxidant activity through free radicalscavenging of single ethanolic extract and their combinations (1:2), (1:1), and (2:1) from $Z$. officinale and $P$. Retrofratum. Antioxidant activities of plant extracts wereusually linked to their phenolic content. Z.officinale contains gingerol compounds and derivatives such as polyphenols that have antioxidant effects (Ghosh, 2011) and according to Dyatmiko (2000) piperine and amidephenol compounds in the P. Retrofractum has antioxidant activity. DPPH scavenging activity of phenolicsis positively correlated with the number of hydroxyl groups. The phenolic compounds contributesignificantly to the antioxidant capacity of the plants ,especially phenolic acids and flavonoids (Djeridane et. al., (2006); (Ignat et al., 2011)). Polyphenols are the major plant compounds with antioxidant activity, although they are not the only ones (Djeridane et al., 2006). The antioxidant activity of phenolic compounds depends on the structure, the number and positions of the hydroxyl groups and the nature of substitutions on the aromatic rings (Balasundram et al, 2006). Antioxidants combat oxidativestress by working to neutralise excess free radicals andstopping them from starting the chain reactions thatcontribute to various diseases and premature aging (Singh et. al., 2004).
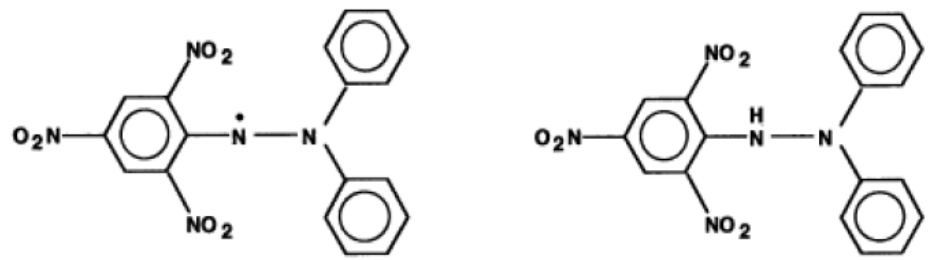

Figure I. Structure free radical and nonradical DPPH

\section{CONCLUSION}

The results showed that the single ethanolic extract of $Z$. Officinalle showed the biggest antioxidant activity $\left(\mathrm{IC}_{50} 56 \mu \mathrm{g} / \mathrm{mL}\right.$ ), while the antioxidant activity $\left(\mathrm{IC}_{50}\right)$ of the single ethanolic extract of $P$. retrofractum was $3.445 \mu \mathrm{g} / \mathrm{mL}$. Antioxdant activity $\left(\mathrm{IC}_{50}\right)$ combination of $Z$. officinale and $P$. retrofratum ethanolic extract (1: 2), (1:1), and (2:1) were $148 \mu \mathrm{g} / \mathrm{mL}, 85 \mu \mathrm{g} / \mathrm{mL}$, and $73 \mu \mathrm{g} / \mathrm{mL}$.

\section{ACKNOWLEDGEMENT}

This work was supported by Research Program funded by Institute for Research and Community Services, Jenderal Soedirman University, Purwokerto.

\section{REFERENCES}

Balasundram. N., Sundram., K. and Samman, S., 2006, Phenolic Compounds in Plants and Agri-Industrial By-Products: Antioxidant Activity, Occurrence, and Potential Uses, Food Chemistry, 99, I9I-203.

Beinfield, H. and Kornglod, E., 2005, Chinese Medicine and Cancer Care, Alternative Therapies, 9(5), 38-52.

Brand-Williams, W., 1995, Use of A Free Radical Methodto Evaluate Antioxidant Activity. Food Science Technology, 28, 25-30.

Djeridane, A., Yousfi, M., Nadjemi,B., Boutassouna, D., Stocker, P. and Vidal, N. 2006, Antioxidant Activity of Some Algerian Medicinal PlantsExtracts Containing Phenolic Compounds, Food Chemistry, 97, 654-660.

Dyatmiko, W., 2000, Testing Antiradikal Free Difenilpikrilhidrazil (DPPH) Ethanol Extracts Some Plants Piperaceae, Institute 
for Research and Community Service University of Airlangga.

Ghosh, A.K., 20II, Zingiber Officinale: Natural Gold, International Journal of Pharma and Bio Sciences, 2, 283-294.

Grassman, J., 2005, Terpenoids as Plant Antioxidants, Available from:http://www.ncbi.nlm.nih.gov/pubmed/l 64 9248I.

Ignat, I., Volf, I. And Popa, V.I., 20II, Critical Review of Methods for Characterisation of Polyphenolic Compounds in Fruits and Vegetables, Food Chemistry, 126, 18211835.

Jagdale, S.C., Kuchekar, B.S., Chabukswar, A.R., Lokhande, P.D. and Raut, C.G., 2009, Antioxidant Activity of Piper longum Linn, International Journal of Bilogical Chemistry, 3(3), I19-125.

Kametani, S., Kikuzaki, H., Honzawa M. and Nakatani, N., 2005, Chemical Constituents of Piper retrofractum Vahl and Their Antioxidant and Radical Scavenging Activities, ITE Letters 6, 64-7I.

Molyneux, P., 2004, The Use of The Stable Free Radical Diphenylpicrylhydrazyl (DPPH) for Estimating Antioxidant Activity, Songklanakarin J.Sci. Techno., 26, 21 I-219.
Nakatani, N., Inatani, R., Ohta, H. and Atsuko, 1986, Nishioka Chemical Constituents of Peppers (Piper spp.) and Application to Food Preservation: Naturally Occurring Antioxidative Compounds, Enviromental Health Perspectives, 67, I35-142.

Senevirathne, M., Kim, S.., Siriwardhana, N., Ha, J.H., Lee, K.W. and Jeon, Y.J., 2006, Reducing Power and Lipid Peroxidation Inhibition Antioxidant Potential of Ecklonia cavaon Reactive Oxygen Species Scavenging, Metal Chelating, Food Science and Technology International, I 2, 27.

Sharma, O.P. and Bhat, T.K., 2009, DPPH Antioxidant Assay Revisited, Food Chemistry, I I3, I202-1205.

Shirin, A.P.R. and Prakash, J., 2010, Chemical Composition and Antioxidant Properties ofGinger Root (Zingiber officinale), Journal of Medicinal Plants Research, 4(24), 2674-2679.

Simanjuntak, P., Fauzy, R., Emelia Devi, L. and Harum, H., 2008, Antioxidant Activity of Single and Combinations Extract of Cyrcuma spp, Jurnal Ilmu Kefarmasian Indonesia, 6(2), 69-74.

Singh, R.P., Sharad, S. and Kapur, S., 2004, Free Radicals and Oxidative Stress in Neurodegenerative Diseases: Relevance of Dietary Antioxidants, JIACM, 5(3), 2I8-25. 